\title{
Arsenic in Soils: Natural Concentration and Adsorption by Oxisols Developed From Different Lithologies
}

\author{
Maurício P. F. Fontes ${ }^{1}$, Cecília C. Almeida ${ }^{1}$, Adriana C. Dias ${ }^{1}$, Sandro M. Caires ${ }^{2}$ \\ \& Guilherme F. Rosa (in memoriam) ${ }^{3}$ \\ ${ }^{1}$ Soil Science Department, Universidade Federal de Viçosa, Viçosa, MG, Brazil \\ ${ }^{2}$ Instituto Federal do Mato Grosso, Juína, MT, Brazil \\ ${ }^{3}$ Chemistry Department, Universidade Federal de Viçosa, Viçosa, MG, Brazil \\ Correspondence: Adriana C. Dias, Soil Science Department, Universidade Federal de Viçosa, Viçosa, MG, \\ 36570-900, Brazil. E-mail: dias.adrianacristina@yahoo.com.br
}

Received: February 9, 2019

Accepted: March 12, 2019 Online Published: May 15, 2019

doi:10.5539/jas.v11n6p260

URL: https://doi.org/10.5539/jas.v11n6p260

\begin{abstract}
Arsenic (As) is a toxic and a carcinogenic element naturally occurring in the environment. Therefore, studies on As natural concentration in soils and its adsorption process are important tools for the evaluation of potential risks of soil contamination in order to adoption of control actions or monitoring of potential As-contamination sources. The objective of this study was to evaluate the natural levels of As and determine the maximum adsorption capacity of As (MACAs) of six Oxisols (Latossolos) of Minas Gerais State, Brazil, developed from different lithologies. The soil sample's total As content was determined using the USEPA 3051A method. The adsorption experiments were performed using different As concentrations, and the MACAs was measured by the Langmuir isotherm. On average, the natural As content in Oxisols was $13.13 \mathrm{mg} \mathrm{kg}^{-1}$, which is above the reference value of soil quality (RVQ) for As, in Brazil $\left(8 \mathrm{mg} \mathrm{kg}^{-1}\right)$. The levels of As in Oxisols originated from metamorphic/igneous rocks were significantly higher than those of Oxisols from sedimentary rocks. Globally, the evaluated soils showed a mean MACAs equal to $2,548 \mathrm{mg} \mathrm{kg}^{-1}$. Soil horizon $B w$ showed a higher MACAs than that of $A$ horizon. In general, the levels of clay, iron oxides, iron forms (especially poorly-crystallized) and organic carbon had a positive influence on MACAs. Although the RVQ for As is well below the MACAs in all soils, the soil adsorbed As naturally present, rendering it unavailable in the soil aqueous phase. Therefore, there was no risk of contamination for human health.
\end{abstract}

Keywords: toxic element, maximum adsorption capacity, soil horizon, reference value of soil quality, environmental pollution

\section{Introduction}

Arsenic (As) is a toxic and carcinogenic element. After the analytical detection of elements in solution has been improved in the last decades, relationships were established between very low As concentrations and (i) some cancer forms (skin, lung, liver, bladder, kidney, and colon), (ii) other common diseases (cardiovascular diseases, diabetes, and anemia), (iii) neurological changes, and (iv) reproductive and immunological dysfunctions in humans (Aviñó et al., 2008).

This metalloid is widely distributed in the environment and occurs in the Earth's crust at concentrations between 0.5 and $2.5 \mathrm{mg} \mathrm{kg}^{-1}$. However, contents above $13 \mathrm{mg} \mathrm{kg}^{-1}$ can be found in clayey sediments (Kabata-Pendias \& Mukherjee, 2007). According to the World Health Organization (WHO, 2001), the levels of As naturally occurring in soils vary from 1 to $40 \mathrm{mg} \mathrm{kg}^{-1}$, with an average of $5 \mathrm{mg} \mathrm{kg}^{-1}$.

Arsenic mobility depends largely on geochemical environmental characteristics, mainly $\mathrm{pH}$, redox potential, and adsorption and desorption equilibrium, which are controlled by soil mineral and organic matrices. Oxide surfaces, especially iron ( $\mathrm{Fe}$ ), aluminum ( $\mathrm{Al}$ ), and manganese $(\mathrm{Mn})$ oxides, have a high affinity for As (Cui \& Weng, 2013), influencing the mobility of this element in the environment. Brazilian climatic conditions increase the weathering degree of Oxisols (Latossolos), wherein the clay fraction is predominantly composed of kaolinites, and $\mathrm{Fe}$ and $\mathrm{Al}$ oxides (Fontes \& Weed, 1991). 
Given the extension and pedogeological diversity of Brazil, national and state environmental agencies have defined guiding values of soil quality (Preston et al., 2014), through the establishment of three distinct thresholds : reference value of quality (RVQ), reference value of prevention (RVP), and reference value of investigation (RVI). These thresholds are based on soil analysis under its natural conditions and risk analysis for human health (Biondi et al., 2011), thus providing a basis for quality assessment (Teng et al., 2009). In the state of Minas Gerais, the RVQ, RVP, and RVI for As are standardized at 8.0, 15.0, and $55.0 \mathrm{mg} \mathrm{Kg}^{-1}$, respectively (CONAMA, 2009; COPAM, 2011).

In gold mining regions of Minas Gerais, such as the "Quadrilátero Ferrífero" (QF) and the county of Paracatu, studies on the content of As in sediments and in water were carried out (Varejão et al., 2011; Andrade et al., 2012; Borba et al., 2017). In the QF region, As contents can reach up to $4500 \mathrm{mg} \mathrm{kg}^{-1}$ in sediments and $350 \mu \mathrm{g} \mathrm{L}^{-1}$ in water (Borba et al., 2017). However, there are relatively few studies on the presence and/or As adsorption in soils, both for the above-mentioned state and for the rest of the country (Campos et al., 2007; Campos et al., 2013; Ferreira et al., 2018).

Therefore, the study aimed to determine the As natural concentrations and the maximum adsorption capacity of As (MACAs) of Oxisols developed from different lithologies, located in the state of Minas Gerais (Brazil).

\section{Materials and Methods}

\subsection{Description of the Sites and Soil Sample Collection}

The present study was conducted in six sites representative of Red Oxisol (Latossolo Vermelho - LV) and Red-Yellow Oxisol (Latossolo Vermelho-Amarelo - LVA) in Minas Gerais state, Brazil (Figure 1).

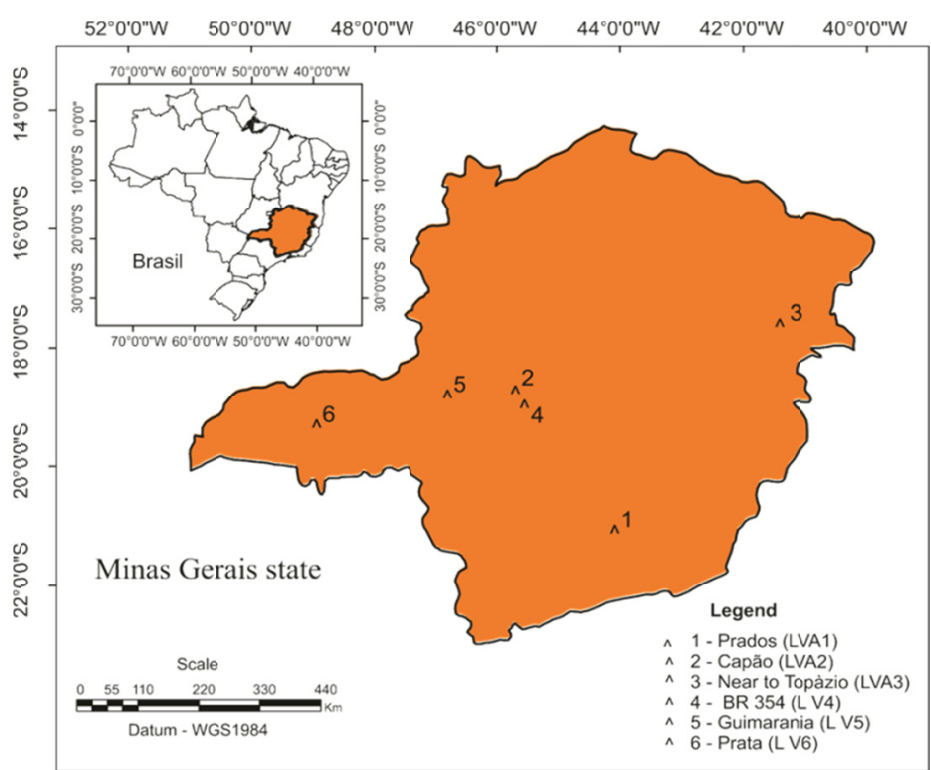

Figure 1. Soil sampling locations for Oxisols (Latossolos) in the Minas Gerais state, Brazil

Details on the geographic coordinates are provided in Table 1.

Table 1. Geographic coordinates of the studied sites

\begin{tabular}{llll}
\hline Site name & Latitude & Longitude & Elevation (m.a.s.1.) \\
\hline Prados & $21^{\circ} 06^{\prime} 31.3^{\prime \prime} \mathrm{S}$ & $44^{\circ} 05^{\prime} 06.8^{\prime \prime} \mathrm{W}$ & 97 \\
Capão & $18^{\circ} 46^{\prime} 05.3^{\prime \prime} \mathrm{S}$ & $45^{\circ} 42^{\prime} 0.14^{\prime \prime} \mathrm{W}$ & 1032 \\
Topázio & $17^{\circ} 38^{\prime} 25.0^{\prime \prime} \mathrm{S}$ & $41^{\circ} 24^{\prime} 53.6^{\prime \prime} \mathrm{W}$ & 306 \\
BR-354 road & $19^{\circ} 00^{\prime} 25.7^{\prime \prime} \mathrm{S}$ & $5^{\circ} 33^{\prime} 14.0^{\prime \prime} \mathrm{W}$ & 886 \\
Guimarania & $18^{\circ} 50^{\prime} 21.8^{\prime \prime} \mathrm{S}$ & $46^{\circ} 47^{\prime} 56.7^{\prime \prime} \mathrm{W}$ & 886 \\
Prata & $19^{\circ} 20^{\prime} 35.7^{\prime \prime} \mathrm{S}$ & $48^{\circ} 56^{\prime} 27.8^{\prime \prime} \mathrm{W}$ & 631 \\
\hline
\end{tabular}


The soils profiles were characterized using samples collected at depths of 0-20 cm ( $A$ horizon) and $50-70 \mathrm{~cm}(B$ horizon), according to soil description and collection criteria (Santos et al., 2005). Two samples of approximately $2 \mathrm{~kg}$ were collected from the central part of each soil surface $(A)$ and subsurface $(B w)$ horizons, characteristic of each profile. The soil samples were dried, crushed, and sieved (2-mm mesh) to obtain the air-dried fine earth (ADFE). Soil was classified according to the Brazilian System of Soil Classification (EMBRAPA, 2013) and the U.S. Soil Taxonomy (Soil Survey Staff, 2014) (Table 2).

Table 2. Classification of the studied Oxisols (Latossolos)

\begin{tabular}{|c|c|c|c|}
\hline Soil Id. & Brazilian Soil Classification & U. S. Soil Taxonomy & Parent material \\
\hline LVA1 & $\begin{array}{l}\text { Dystrophic Red-Yellow Oxisol } \\
\text { (Latossolo Vermelho-Amarelo Distrófico) }\end{array}$ & Acrudox & Granites/Gneisses \\
\hline LVA2 & $\begin{array}{l}\text { Dystrophic Red-Yellow Oxisol } \\
\text { (Latossolo Vermelho-Amarelo Distrófico) }\end{array}$ & Acrudox & Mafic/Ultramafic \\
\hline LVA3 & $\begin{array}{l}\text { Dystrophic Red-Yellow Oxisol } \\
\text { (Latossolo Vermelho-Amarelo Distrófico) }\end{array}$ & Hapludox & Granites/Gneisses \\
\hline LV4 & $\begin{array}{l}\text { Dystrophic Red Oxisol } \\
\text { (Latossolo Vermelho Distrófico) }\end{array}$ & Acrudox & Mafic/Ultramafic \\
\hline LV5 & $\begin{array}{l}\text { Dystrophic Red Oxisol } \\
\text { (Latossolo Vermelho Distrófico) }\end{array}$ & Hapludox & Argillite/Siltite \\
\hline LV6 & $\begin{array}{l}\text { Dystrophic Red Oxisol } \\
\text { (Latossolo Vermelho Distrófico) }\end{array}$ & Hapludox & Sandstone \\
\hline
\end{tabular}

\subsection{Physical, Chemical and Mineralogical Characterization of the Soils}

Grain size distribution (physical characterization) was analyzed for all soil samples (EMBRAPA, 2011). In previous studies, all the soil profiles studied here had been characterized chemically and mineralogically for total organic carbon (TOC) (Yeomans \& Bremner, 1988), $\mathrm{Fe}$ oxalate ( $\mathrm{Fe}_{\mathrm{OXX}}$ ) (McKeague \& Day, 1966), $\mathrm{Fe}$ dithionite-citrate $\left(\mathrm{Fe}_{\mathrm{D}}\right)$ (Coffin, 1963), pH (EMBRAPA, 2011), Zero Point of Charge of Saline Effect (ZPCSE) (Fontes et al., 2001), and X-Ray diffractometry (X'pert PRO Diffractometer, Fe filter and CoK $\alpha$ radiation). Table 3 displays the results of chemical and mineralogical characterization.

Table 3. Chemical and mineralogical characterization of clay fraction in the studied soils

\begin{tabular}{lllllllll}
\hline Soil & Horizon & $\mathrm{pH}$ & ZPCSE & $\mathrm{TOC}$ & $\mathrm{Fe}_{\mathrm{D}}$ & $\mathrm{Fe}_{\mathrm{OX}}$ & $\mathrm{Fe}_{\mathrm{OX}} / \mathrm{Fe}_{\mathrm{D}}$ & Mineralogy \\
\hline LVA1 & $\mathrm{A}$ & 4.94 & 3.64 & 2.73 & 7.43 & 0.10 & 0.01 & $\mathrm{Kt}, \mathrm{Gb}, \mathrm{Gt}, \mathrm{Il}, \mathrm{Hm}$ \\
LVA1 & $\mathrm{Bw}$ & 4.98 & 4.89 & 0.91 & 4.16 & 0.59 & 0.14 & $\mathrm{Kt}, \mathrm{Gb}, \mathrm{Gt}, \mathrm{Il}, \mathrm{Hm}$ \\
LVA2 & $\mathrm{A}$ & 4.94 & 3.85 & 2.99 & 6.34 & 0.13 & 0.02 & $\mathrm{Il}, \mathrm{Kt}, \mathrm{Gb}, \mathrm{Hm}, \mathrm{Gt}$ \\
LVA2 & $\mathrm{Bw}$ & 5.07 & 4.99 & 1.66 & 5.41 & 0.73 & 0.13 & $\mathrm{Il}, \mathrm{Kt}, \mathrm{Gb}, \mathrm{Hm}, \mathrm{Gt}$ \\
LVA3 & $\mathrm{A}$ & 5.06 & 3.25 & 1.55 & 1.74 & 0.11 & 0.06 & $\mathrm{Kt}, \mathrm{Gb}, \mathrm{Gt}$ \\
LVA3 & $\mathrm{Bw}$ & 5.07 & 4.96 & 0.73 & 1.61 & 1.20 & 0.74 & $\mathrm{Kt}, \mathrm{Gb}, \mathrm{Gt}$ \\
LV4 & $\mathrm{A}$ & 4.50 & 3.52 & 8.22 & 4.09 & 2.02 & 0.49 & $\mathrm{Kt}, \mathrm{Gb}, \mathrm{Gt}, \mathrm{Hm}, \mathrm{Il}$ \\
LV4 & $\mathrm{Bw}$ & 4.81 & 3.76 & 3.29 & 5.42 & 3.22 & 0.59 & $\mathrm{Kt}, \mathrm{Gb}, \mathrm{Gt}, \mathrm{Hm}, \mathrm{Il}$ \\
LV5 & $\mathrm{A}$ & 4.87 & 4.25 & 1.55 & 5.03 & 0.17 & 0.03 & $\mathrm{HIV}, \mathrm{Il}, \mathrm{Kt}, \mathrm{Gb}, \mathrm{Gt}, \mathrm{Mh}, \mathrm{Hm}$ \\
LV5 & $\mathrm{Bw}$ & 5.32 & 4.42 & 0.95 & 4.27 & 0.99 & 0.23 & $\mathrm{HIV}, \mathrm{Il}, \mathrm{Kt}, \mathrm{Gb}, \mathrm{Gt}, \mathrm{Mh}, \mathrm{Hm}$ \\
LV6 & $\mathrm{A}$ & 5.97 & 3.50 & 1.15 & 9.69 & 0.56 & 0.05 & $\mathrm{Kt}, \mathrm{Gb}, \mathrm{Gt}, \mathrm{Il}, \mathrm{Mh}, \mathrm{Hm}$ \\
LV6 & $\mathrm{Bw}$ & 4.84 & 3.54 & 0.43 & 10.47 & 0.44 & 0.04 & $\mathrm{Kt}, \mathrm{Gb}, \mathrm{Gt}, \mathrm{Il}, \mathrm{Mh}, \mathrm{Hm}$ \\
\hline
\end{tabular}

Note. ZPCSE: Zero Point of Charge of Saline Effect; TOC: Total Organic Carbon (dag kg $\left.{ }^{-1}\right) . \mathrm{Fe}_{\mathrm{D}}$ : Fe extracted by dithionite-citrate; $\mathrm{Fe}_{\mathrm{OX}}$ : $\mathrm{Fe}$ extracted by oxalate; $\mathrm{Kt}=$ Kaolinite; $\mathrm{Gb}=$ Gibbsite; $\mathrm{Gt}=$ Goethite; $\mathrm{Hm}=$ Hematite; Il: Illite; Mh: Maghemite; HIV: Hydroxy Interlayer Vermiculite.

\subsection{Natural Levels of Arsenic in the Soils}

In the laboratory, soil sub-samples were finely ground in an agate mortar in triplicate and then digested using the USEPA 3051A method (USEPA, 2007) in a microwave oven Milestone Ethos Pró (Milestone, Sorisole, Italy) for 
the determination of As natural contents. The determination was performed using standard samples (SS-1) (EnviroMAT SCP Science ${ }^{\circledR}$, Baie D’Urfe, Quebec, Canada) with certified values as controls.

Analytical extracts were used to measure As natural contents by inductively coupled plasma-optical emission spectrometry (ICP-OES Optima 3.300 DV, Perkin-Elmer, Norwalk, CT, USA) with a limit of detection of $7 \mu \mathrm{g}$ $\mathrm{L}^{-1}$. Calibration curve solutions ( 0 to $100 \mathrm{ppm}$ ) were prepared from the dilution of the Merck-Titrisol As standard (1000 ppm). $\mathrm{HNO}_{3}$ (Merck, Rio de Janeiro, Brazil) was used for the preparation of the solutions and preservation and dilution of the samples. Arsenic levels obtained in the analyses were compared using the Student's t-test for non-homogeneous variances at $1 \%$ probability level.

\subsection{Arsenic Adsorption}

Arsenic adsorption was assessed in triplicate for the $\mathrm{A}$ horizon and $\mathrm{B}$ horizon soil samples, using $0.001 \mathrm{~mol} \mathrm{~L}^{-1}$ $\mathrm{NaNO}_{3}$ solutions (Merck, Rio de Janeiro, Brazil) containing $\mathrm{Na}_{2} \mathrm{HAsO}_{4} \cdot 7 \mathrm{H}_{2} \mathrm{O}$ (Sigma-Aldrich, São Paulo, Brazil) at the following concentrations: $0.00,0.08,0.16,0.24,0.40,0.56,0.72,0.88,1.12,1.36$, and $1.60 \mathrm{mmol} \mathrm{L}^{-1}$ of As $(\mathrm{V})$, with $\mathrm{pH}$ adjusted to 5.5. A mass of $0.5 \mathrm{~g}$ of each soil was added to $50 \mathrm{~mL}$ of $\mathrm{As}(\mathrm{V})$ solution, in polypropylene tubes. These soil suspensions were mixed by vertical stirring at $45 \mathrm{rpm}$ for 24 hours. The suspensions were centrifuged, and the supernatants were filtered, for determination of As contents by ICP-OES.

The maximum adsorption capacity of As(V) (MACAs) was evaluated using the Langmuir isotherm, according to Equation 1.

$$
x / m=a b C /(1+a C)
$$

where, $\mathrm{x} / \mathrm{m}$ is the amount of element adsorbed per unit of weight of absorbent $\left(\mathrm{mg} \mathrm{g}^{-1}\right), \mathrm{b}$ is the maximum adsorption capacity of element by the soil $\left(\mathrm{mg} \mathrm{g}^{-1}\right), \mathrm{C}$ is the element concentration in the equilibrium solution, or final solution, after the adsorption experiments $\left(\mathrm{mg} \mathrm{L}^{-1}\right)$, and $a$ is a constant related to the binding energy between element and the soil $\left(\mathrm{L} \mathrm{mg}^{-1}\right)$ (Fontes, 2012).

\section{Results}

\subsection{Soil Physical Characterization (Grain Size Distribution)}

The evaluated soils presented a well-differentiated textural class, ranging from sandy-loam to clayey (Table 4). Red-Yellow Oxisol (LVA1, LVA2, and LVA3) presented high levels of clay, with a texture ranging from clayey to very clayey. On the other hand, Red Oxisol (LV4, LV5, and LV6) presented a wide range of clay contents, from sandy-loam to very clayey, which may be due to the heterogeneity of their source materials.

Table 4. Physical characterization of the studied soils

\begin{tabular}{|c|c|c|c|c|c|c|}
\hline Soil & Horizon & Sandy & Silt & Clay & Silt/Clay & Textural Class \\
\hline \multicolumn{7}{|c|}{ 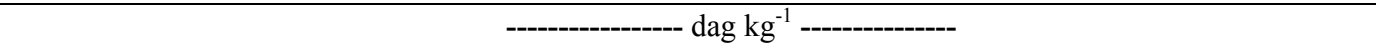 } \\
\hline LVA1 & A & 23 & 13 & 64 & 0.20 & Very clayey \\
\hline LVA1 & $\mathrm{Bw}$ & 21 & 11 & 68 & 0.16 & Very clayey \\
\hline LVA2 & A & 7 & 13 & 80 & 0.16 & Very clayey \\
\hline LVA2 & $\mathrm{Bw}$ & 5 & 12 & 83 & 0.14 & Very clayey \\
\hline LVA3 & A & 44 & 10 & 48 & 0.20 & Clayey \\
\hline LVA3 & Bw & 31 & 7 & 62 & 0.11 & Very clayey \\
\hline LV4 & A & 12 & 23 & 65 & 0.35 & Very clayey \\
\hline LV4 & Bw & 6 & 11 & 83 & 0.13 & Very clayey \\
\hline LV5 & A & 42 & 29 & 29 & 1.00 & Clay loam \\
\hline LV5 & $\mathrm{Bw}$ & 36 & 24 & 40 & 0.60 & Clayey \\
\hline LV6 & A & 82 & 7 & 14 & 0.50 & Sandy loam \\
\hline LV6 & $\mathrm{Bw}$ & 77 & 6 & 17 & 0.35 & Sandy loam \\
\hline
\end{tabular}

\subsection{Natural Levels of Arsenic}

Natural levels of As in the soil classes evaluated are shown in the Table 5. The concentrations of As of LV (Red Oxisol), whose LV5 and LV6 originate from sedimentary material (Table 2), were lower than those of LVA (Red-Yellow Oxisol), which was formed by metamorphic/igneous rocks. When horizons were compared, the levels of As in $B w$ of LV were superior to those of the surface (or $A$ ) horizon. Yet, in LVA, no statistical 
difference was found between the horizons. Also, in LV, the $B w$ horizon of LV4 showed a $126 \%$ increase in As content when the $A$ horizon was compared to the subsurface (or $B w$ ) horizon (Table 5); this may be due to the higher clay content of $B w$ horizon (Table 4).

Table 5. Natural levels of arsenic, in $\mathrm{mg} \mathrm{kg}^{-1}$, in the studied soils

\begin{tabular}{lll|lll}
\hline Soil & $A$ Horizon & $B w$ Horizon & Soil & A Horizon & $B w$ Horizon \\
\hline LVA1 & 16.66 & 13.83 & LV4 & 7.11 & 16.07 \\
LVA2 & 24.02 & 29.19 & LV5 & 4.91 & 2.46 \\
LVA3 & 8.97 & 18.00 & LV6 & 8.43 & 7.86 \\
Mean & $16.55 \mathrm{a}$ & $20.35 \mathrm{a}$ & Mean & $6.81 \mathrm{~b}$ & $8.79 \mathrm{a}$ \\
Variance & 56.63 & 63.09 & Variance & 3.16 & 8.79 \\
LVA mean & $18.45 \mathrm{a}$ & & LV mean & $7.80 \mathrm{~b}$ & \\
Variance & 52.19 & & Variance & 21.23 & \\
\hline
\end{tabular}

Note. Mean followed by the same letter in the lines, for the same soil class, do not differ from each other.

Conversely, in LV5, the levels of As fell by $50 \%$ from the surface horizon to the $B w$ horizon. This might be hypothetically due the anthropic action towards the most superficial horizon to the detriment of the geological material layer (clay/silt). The LV6, that had a coarser grain size distribution (Table 4), presented As contents of $8.43 \mathrm{mg} \mathrm{kg}^{-1}$ and $7.86 \mathrm{mg} \mathrm{kg}^{-1}$ for $A$ and $B w$ horizons, respectively, values near to the mean of this soil class.

The mean As content in the evaluated soils was $13.13 \mathrm{mg} \mathrm{kg}^{-1}$. This value is above the RVQ $\left(8 \mathrm{mg} \mathrm{kg}^{-1}\right)$ and below the RVP $\left(15 \mathrm{mg} \mathrm{kg}^{-1}\right)$ for Minas Gerais, as shown in Figure 2.

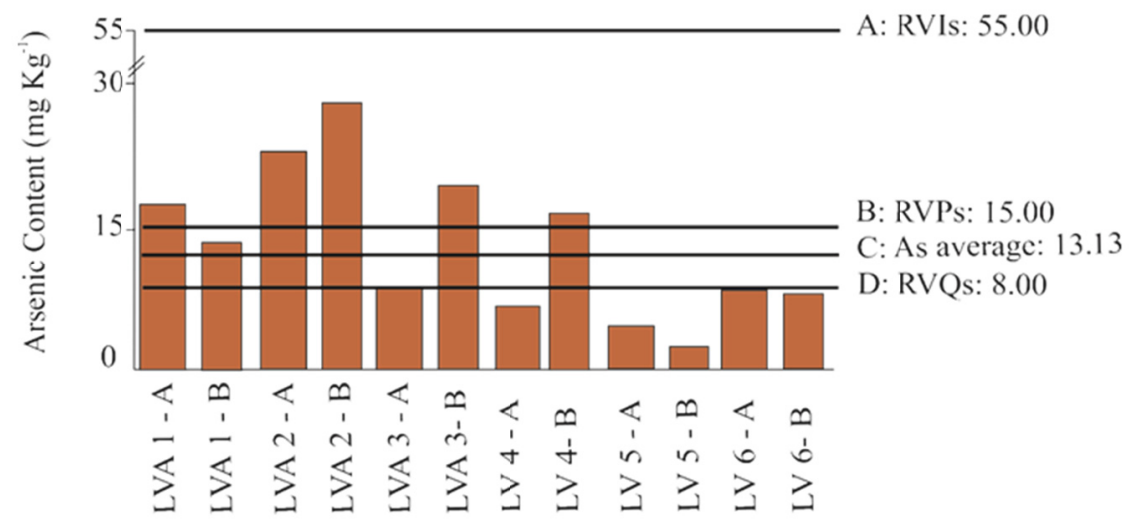

Figure 2. Arsenic content in the studied Oxisols (Latossolos). A: Reference Value of Investigation for As in soils (RVI); B: Reference Value of Prevention for As in soils (RVP); C: Average As content in the studied Oxisols, D: Reference Value of Quality for As in soils (RVQ)

Note. These reference values are for the state of Minas Gerais, Brazil.

In general, when As concentrations in soil are below the RVQ or it is between the quality thresholds of RVQ and RVP, neither control actions nor monitoring of potential contamination sources is needed. However, for As concentrations between RVP and RVI (55 mg kg $\mathrm{g}^{-1}$ ), the identification of contamination sources and/or natural anomalies may be required for soil monitoring purposes. This is the case of soil LVA2, which has levels of As above $26 \mathrm{mg} \mathrm{kg}^{-1}$. Indeed, if As contents are equal to or greater than RVI, contamination mitigation measures must be taken, because such levels may result in risks to human health.

\subsection{Maximum Adsorption Capacity of Arsenic}

Table 6 shows the data on As adsorption adjusted according to the Langmuir equation. Regression coefficients $\left(\mathrm{R}^{2}\right)$ ranged from 0.97 to 0.99 , indicating that the model has described As adsorption efficiently. 
Table 6. Parameters related to the Langmuir equation for As adsorption in the studied Oxisols (Latossolos)

\begin{tabular}{lllll|lllll}
\hline Soil & Horizon & $\mathrm{b}$ & $\mathrm{a}$ & $\mathrm{R}^{2}$ & Soil & Horizon & $\mathrm{b}$ & $\mathrm{a}$ & $\mathrm{R}^{2}$ \\
\hline & & $\mathrm{mg} \mathrm{kg}^{-1}$ & $\mathrm{~L} \mathrm{mg}^{-1}$ & & & & $\mathrm{mg} \mathrm{kg}$ & $\mathrm{L} \mathrm{mg}^{-1}$ & \\
LVA1 & $\mathrm{A}$ & 2490.0 & 1.4 & 0.99 & LV4 & $\mathrm{A}$ & 3560.0 & 1.3 & 0.99 \\
LVA1 & Bw & 2550.0 & 1.5 & 0.99 & LV4 & Bw & 3580.0 & 1.4 & 0.99 \\
LVA2 & $\mathrm{A}$ & 2450.0 & 1.0 & 0.99 & LV5 & $\mathrm{A}$ & 2190.0 & 1.3 & 0.99 \\
LVA2 & Bw & 2670.0 & 1.1 & 0.99 & LV5 & Bw & 2460.0 & 1.3 & 0.97 \\
LVA3 & A & 2240.0 & 1.4 & 0.98 & LV6 & A & 1769.0 & 1.0 & 0.99 \\
LVA3 & Bw & 2850.0 & 1.2 & 0.99 & LV6 & Bw & 1780.0 & 1.3 & 0.99 \\
\hline
\end{tabular}

The maximum adsorption capacity of As (MACAs) varied between 3580.0 and $1769.0 \mathrm{mg} \mathrm{kg}^{-1}$. The highest value was found in a soil developed from mafic/ultramafic rocks (LV4- $B w$ ), while the lowest one was observed in a soil developed from sandstones (LV6-A). The LVA presented a mean MACAs of $2541.7 \mathrm{mg} \mathrm{kg}^{-1}$, which is slightly lower than that of the LV soil class $\left(2556.5 \mathrm{mg} \mathrm{kg}^{-1}\right)$. The overall mean of MACAs of the six soils studied here was $2549.1 \mathrm{mg} \mathrm{kg}^{-1}$.

\section{Discussion}

Physical, chemical and/or mineralogical differences between soil classes may be due to the heterogeneity of their parent material and it are characteristics that promote differences in natural levels of As present in the soils and in the As adsorption by soils. As mentioned, the MACAs of LV is slightly higher than that presented by LVA (Table 6). However, natural levels of As are lower in LV class when compared to those of LVA (Table 5). The LV soil class (the one with the lowest overall As content) presented both the highest MACAs in LV4 and the lowest MACAs in LV6. These results indicate that the natural levels of As in this soil class had no direct influence on As adsorption.

The $B w$ horizon of the studied soils presented As adsorption higher than that of surface horizons. It might be due to the lower total organic carbon (TOC) contents of $B w$ in relation to the $A$ horizons, which reduces competition for adsorption sites, besides a higher content of poorly crystallized $\mathrm{Fe}$, as evidenced by the high values of $\mathrm{Fe}_{\mathrm{OX}}$ content and $\mathrm{Fe}_{\mathrm{OX}} / \mathrm{Fe}_{\mathrm{D}}$ ratio (Table 3).

Iron and aluminum oxy-hydroxides, especially those poorly crystallized, with high surface area, have favorable characteristics for As adsorption. Chemical reactivity of inner-coordinate surface functional groups makes these surfaces strong sorbents of As (McBride, 1994). Since the adsorption process, involves the strong affinity of the $\mathrm{Fe}$ and $\mathrm{Al}$ oxy-hydroxides, for As, it is strongly attracted to the adsorption sites on solid surfaces and is effectively removed from solution (Johnston \& Heijnen, 2001).

The LV4 presented the highest MACAs, which was due to its very clayey texture (Table 4) together with a predominance of $\mathrm{Fe}$ oxides, as it is developed from mafic/ultramafic materials (Table 2). This $\mathrm{Fe}$ was predominantly in a poorly crystallized form (Table 3), which confers a high specific surface to this mineral and hence to the soil, thus increasing adsorption sites. LV6, which was developed from sandstones (Table 2) and has a sandy-loam texture, stands out for the lowest MACAs of the study (1769.0 and $1780.0 \mathrm{mg} \mathrm{kg}^{-1}$, respectively for $A$ and $B w$ horizons). In this soil, allied to the low amount of clay was a predominance of $\mathrm{Fe}$ in well-crystallized form, that is, a high $\mathrm{Fe}_{\mathrm{D}}$ value (Table 3), which seems to corroborate its lower As adsorption capacity.

Soil texture influence on As adsorption was evidenced in the evaluation of MACAs in diverse Japanese soils (Sultana \& Kobayashi, 2016). The authors found the highest As adsorption in a clay-loam soil, followed by a loam soil, and last, by adsorbing less, a sandy-loam soil.

Similar results were found in the evaluation of MACAs using as adsorbent the clay fraction of different soils located in Antarctica (Poggere et al., 2017). These authors obtained a mean MACAs of $3554.0 \mathrm{mg} \mathrm{kg}^{-1}$ and they concluded that a soil mineralogical composition is more important than its clay content for MACAs evaluations since poorly-crystallized $\mathrm{Fe}$ and $\mathrm{Al}$ oxides are mainly responsible for As adsorption. It is worth mentioning that Fe oxides and hydroxides, especially those with low crystallinity, have favorable characteristics as anion adsorbents for having numerous $\mathrm{OH}^{-}$ions on the surface. These ions have unsatisfied valences responsible for exchange of binders and electrostatic attraction interactions. Studies using Fe oxides, such as goethite, for remediation of As-contaminated water sources concluded that As retention on goethite surface occurs by diverse complexation mechanisms: (i) predominantly monodentate complexation, for low-load adsorbent surfaces; (ii) 
bidentate bonding, for high-load surfaces, and (iii) mono and bidentate bonding, for medium-load adsorbent surfaces (Fendorf et al., 1997).

The evaluation of As adsorption in three different soil classes in Taiwan showed that MACAs increased as the amount of Fe, Al, and Mn oxides increased in the soils (Chien et al., 2015). Studies in the literature show similar results and conclude that one of the leading causes of $\mathrm{As}(\mathrm{V})$ adsorption to adsorbent materials is a high concentration of oxides, such as Fe oxides (Zhang et al., 2013).

The values of MACAs lower than a mean of this study $\left(2549.1 \mathrm{mg} \mathrm{kg}^{-1}\right)$ were found in one study that evaluated 17 Brazilian Oxisols, whose mean MACAs was $2013.0 \mathrm{mg} \mathrm{kg}^{-1}$ (Campos et al., 2007). The authors concluded that the largest MACAs were found in soils rich in clay and $\mathrm{Fe}$ and $\mathrm{Al}$ oxides.

Such statements corroborate the fact that one of the aspects culminating in a higher or lower As adsorption in soils refers to the content of oxides therein. The evaluated Oxisols presented a high adsorption capacity for As, which is common in this soil class. In a study of three soil classes in China, the authors inferred that soils classified as Oxisol have the highest MACAs if compared to a Mollisol (Chernossolo) or to those derived from volcanic rocks (Feng et al., 2013).

Assessing the relationship between physical and chemical properties, another study on 16 Chinese soils (Jiang et al., 2005) concluded that $93.8 \%$ of $\mathrm{As}(\mathrm{V})$ adsorption variability in soils can be described by their contents of TOC, clay, and $\mathrm{Fe}_{\mathrm{D}}$. In soils with higher binding energy, $87.7 \%$ of $\mathrm{As}(\mathrm{V})$ adsorption was attributed to TOC, clay content, $\mathrm{Fe}_{\mathrm{D}}$ contents and to As natural concentrations. However, regardless of binding energy, these authors stated that the most influencing characteristic for $\mathrm{As}(\mathrm{V})$ adsorption to soil is related to $\mathrm{Fe}_{\mathrm{D}}$.

Conversely, our findings showed that As adsorption capacity in Oxisols was mainly related to factors such as soil texture, TOC, and Fe forms (well or poorly crystallized) since the clay-fraction mineralogy of the studied soils remained relatively unchanged throughout the soil profile. For example, LV4 (soil with higher MACAs) and LV6 (soil with the lowest MACAs) were composed of the same minerals, e.g., kaolinite, gibbsite, hematite, and illite, differing only by the presence of maghemite in LV6 (Table 3).

\section{Conclusion}

Oxisols developed from sedimentary parent materials presented a natural arsenic (As) content inferior to those in soils from granite/gneiss and mafic/ultramafic rocks.

In most of the studied Oxisols, As levels were above the thresholds of Reference Value of Quality and Reference Value of Prevention for As in soil. However, their high maximum adsorption capacity of As (MACAs) provides the retention of this contaminant in the soil solid phase.

The MACAs was efficiently described by the Langmuir isotherm for all the studied soils. $B$ horizons showed higher As adsorption due to the smaller content of total organic carbon in this layer, as well as the predominance of Fe oxides in poorly-crystallized forms.

Among the Oxisols evaluated, As adsorption capacity had no relationship with the natural content of this element in the soils deemed "uncontaminated". Red Oxisols class presented the lowest natural level of As, but it also comprised both soils with high and low MACAs.

Among the studied soils, Dystrofic Red Oxisol (Acrudox), which has a very clayey texture and was developed from mafic/ultramafic rocks, stood out for the largest MACAs. In contrast, the lowest MACAs were presented by Dystrofic Red Oxisol (Hapludox), which has a sandy-loam texture and was formed from sandstones.

\section{Acknowledgements}

The authors are grateful to the Conselho Nacional de Desenvolvimento Científico e Tecnológico-CNPq, Brazil and Coordenação de Aperfeiçoamento de Pessoal de Nível Superior-CAPES, Brazil, for the fellowships.

\section{References}

Andrade, R. P., Mello, J. W. V., Windmöller, C. C., Silva, J. B. B., \& Figueiredo, B. R. (2012). Evaluation of arsenic availability in sulfidic materials from gold mining areas in Brazil. Water, Air, \& Soil Pollution, 223(8), 4679-4686. https://doi.org/10.1007/s11270-012-1224-3

Aviñó, R. B., Lópes-Moya, J. R., \& Navarro-Aviñó, J. P. (2008). Health implications: Trace elements in cancer. In M. N. V. Prasad (Ed.), Trace elements as contaminants and nutrients: Consequences in ecosystems and human health (pp. 495-521). New Jersey: John Wiley \& Sons. https://doi.org/10.1002/9780470370124.ch20 
Biondi, C. M., Nascimento, C. W. A., \& Neta, A. D. B. F. (2011). Teores naturais de bário em solos de referência do estado de Pernambuco. Revista Brasileira de Ciência do Solo, 35(5), 1819-1826. https://doi.org/10.1590/S0100-06832011000500036

Borba, R. P., Figueiredo, B. R., Rawlins, B., \& Matschullat, J. (2017). Arsenic in water and sediment in the iron quadrangle, state of Minas Gerais, Brazil. Revista Brasileira de Geociências, 30(3), 558-561. https://doi.org/10.25249/0375-7536.2000303558561

Campos, M. L., Guilherme, L. R. G., Lopes, R. S., Antunes, A. S., Marques, J. J. G. D. S. E. M., \& Curi, N. (2007). Teor e capacidade máxima de adsorção de arsênio em Latossolos brasileiros. Revista Brasileira de Ciência do Solo, 31(6), 1311-1318. https://doi.org/10.1590/S0100-06832007000600010

Campos, M. L., Guilherme, L. R. G., Marques, J. J. G. D. S. E. M., Curi, N., Araújo, A. S. A., Miquelluti, D. J., ... Spiazzi, F. R. (2013). Teores de arsênio e cádmio em solos do bioma cerrado. Revista Brasileira de Ciência do Solo, 37(1), 281-286. https://doi.org/10.1590/S0100-06832013000100029

Chien, S. W. C., Chen, S. H. \& Huang, K. J. (2015). Arsenic of adsorption characteristics in Taiwan soils. Journal of Applied Science and Engineering, 18(4), 323-330. https://doi.org/10.6180/jase.2015.18.4.02

Coffin, D. E. (1963). A method for the determination of free iron in soils and clays. Canadian Journal of Soil Science, 43(1), 7-17. https://doi.org/10.4141/cjss63-002

CONAMA (Conselho Nacional do Meio Ambiente). (2009). Resolução $N^{o} 420$. Brasília, Brasil: Ministério do Desenvolvimento Urbano e Meio Ambiente.

COPAM (Conselho Estadual de Política Ambiental). (2011). Deliberação Normativa $N^{\circ}$ 166. Belo Horizonte, Brasil.

Cui, Y., \& Weng, L. (2013). Arsenate and phosphate adsorption in relation to Oxides composition in soils: LCD modeling. Environmental Science \& Technology, 47(13), 7269-7276. https://doi.org/10.1021/es400526

EMBRAPA (Empresa Brasileira de Pesquisa Agropecuária). (2011). Manual de métodos de análise de solos. Rio de Janeiro, RJ, Brasil: Embrapa Solos.

EMBRAPA (Empresa Brasileira de Pesquisa Agropecuária). (2013). Sistema brasileiro de classificação de solos. Rio de Janeiro, RJ, Brasil: Embrapa Solos.

Fendorf, S., Eick, M. J., Grossl, P., \& Sparks, D. L. (1997). Arsenate and chromate retention mechanisms on goethite. 1. Surface structure. Environmental Science \& Technology, 31(2), 315-320. https://doi.org/ $10.1021 /$ es 950653

Feng, Q., Zhang, Z., Chen, Y., Liu, L., Zhang, Z., \& Chen, C. (2013). Adsorption and desorption characteristics of arsenic on soils: Kinetics, equilibrium, and effect of $\mathrm{Fe}(\mathrm{OH})_{3}$ colloid, $\mathrm{H}_{2} \mathrm{SiO}_{3}$ colloid and phosphate. Procedia Environmental Sciences, 18, 26-36. https://doi.org/10.1016/j.proenv.2013.04.005

Ferreira, E. P., Coelho, R. M., Valladares, G. S., Dias, L. M. D. S., Assis, A. C. C. D., Silva, R. C. D., ... Abreu, C. a. D. (2018). Mineralogy and concentration of potentially toxic elements in soils of the São Francisco sedimentary basin. Revista Brasileira de Ciência do Solo, 42, e0170088. https://doi.org/10.1590/ $18069657 \mathrm{rbcs} 20170088$

Fontes, M. P. (2012). Behavior of heavy metals in soils: Individual and multiple competitive adsorption. In H. M. Selim (Eds.) Competitive Sorption and Transport of Heavy Metals in Soils and Geological Media (pp. 77-118.) New York: CRC Press: Boca Raton, FL.

Fontes, M. P. F., Camargo, O. A., \& Sposito, G. (2001). Eletroquímica das partículas coloidais e sua relação com a mineralogia de solos altamente intemperizados. Scientia Agricola, 58(3), 627-646. https://doi.org/ 10.1590/S0103-90162001000300029

Fontes, M. P. F., \& Weed, S. B. (1991). Iron oxides in selected Brazilian Oxisols: I. Mineralogy. Soil Science Society of America Journal, 55(4), 1143-1149. https://doi.org/10.2136/sssaj1991.03615995005500040040x

Jiang, W., Zhang, S., Shan, X.-Q., Feng, M., Zhu, Y.-G., \& Mclaren, R. G. (2005). Adsorption of arsenate on soils. Part 1: Laboratory batch experiments using 16 Chinese soils with different physiochemical properties. Environmental Pollution, 138(2), 278-284. https://doi.org/10.1016/j.envpol.2005.03.007

Johnston, R., \& Heijnen, H. (2001). Safe water technology for arsenic removal. In M. F. Ahmed, M. A. Ali, \& Z. Adeel (Eds.), Technologies for arsenic removal from drinking water (pp. 7-12.) Dhaka: Bangladesh University of Engineering and Technology. 
Kabata-Pendias, A., \& Mukherjee, A. B. (2007). Trace elements from soil to human. New York: Springer-Verlag. https://doi.org/10.1007/978-3-540-32714-1

Mcbride, M. B. (1994). Chemisorption and precipitation of inorganic ions. Environmental chemistry of soils. Oxford University Press: New York.

Mckeague, J. A., \& Day, J. H. (1966). Dithionite- and oxalate-extractable Fe and Al as AIDS in differentiating various classes of soils. Canadian Journal of Soil Science, 46(1), 13-22. https://doi.org/10.4141/cjss66-003

Poggere, G. C., Melo, V. D. F., Francelino, M. R., Simas, F. N. B., \& Schaefer, C. E. G. R. (2017). Adsorption of arsenate $\left(\mathrm{HAsO}_{4}{ }^{2-}\right)$ by the clay fraction of soils of the Keller and Barton Peninsulas, King George Island, Maritime Antarctic. Revista Ciência Agronômica, 48(1), 13-21. https://doi.org/10.5935/1806-6690. 20170002

Preston, W., Nascimento, C. W. A., Biondi, C. M., Souza Junior, V. S., Silva, W. R., \& Ferreira, H. A. (2014). Valores de referência de qualidade para metais pesados em solos do Rio Grande do Norte. Revista Brasileira de Ciência do Solo, 38(3), 1028-1037. https://doi.org/10.1590/S0100-06832014000300035

Santos, R. D., Lemos, R. C., Santos, H. G., Ker, J. C., \& Anjos, L. H. C. (2005). Manual de descrição e coleta de solo no campo. Viçosa, Minas Gerais: Sociedade Brasileira de Ciência do Solo.

Soil Survey Staff. (2014). Keys to Soil Taxonomy. Washington, DC, USA: USDA-Natural Resources Conservation Service.

Sultana, R., \& Kobayashi, K. (2016). Adsorption of arsenic on soil under different soil moisture conditions. Pollution, 2(2), 211-220. https://doi.org/10.7508/pj.2016.02.009

Teng, Y., Ni, S., Wang, J., \& Niu, L. (2009). Geochemical baseline of trace elements in the sediment in Dexing area, South China. Environmental Geology, 57(7), 1649-1660. https://doi.org/10.1007/s00254-008-1446-2

USEPA (United States Environmental Protection Agency). (2007). Method 3051A. Environmental Protection Agency, Washington, DC, US.

Varejão, E. V. V., Bellato, C. R., Fontes, M. P. F., \& Mello, J. W. V. (2011). Arsenic and trace metals in river water and sediments from the southeast portion of the Iron Quadrangle, Brazil. Environmental Monitoring and Assessment, 172(1), 631-642. https://doi.org/10.1007/s10661-010-1361-3

WHO (World Health Organization). (2001). Environmental levels and human exposure. Arsenic and arsenic compounds. Geneva: Environmental Health Criteria 224.

Yeomans, J. C., \& Bremner, J. M. (1988). A rapid and precise method for routine determination of organic carbon in soil. Communications in Soil Science and Plant Analysis, 19(13), 1467-1476. https://doi.org/ $10.1080 / 00103628809368027$

Zhang, G., Ren, Z., Zhang, X., \& Chen, J. (2013). Nanostructured iron(III)-copper(II) binary oxide: A novel adsorbent for enhanced arsenic removal from aqueous solutions. Water Research, 47(12), 4022-4031. https://doi.org/10.1016/j.watres.2012.11.059

\section{Copyrights}

Copyright for this article is retained by the author(s), with first publication rights granted to the journal.

This is an open-access article distributed under the terms and conditions of the Creative Commons Attribution license (http://creativecommons.org/licenses/by/4.0/). 